\title{
Evaluation of Fungicides against Leaf Spot Disease of Pearl Millet Caused by Drechslera setariae under Field Conditions
}

\author{
Rajendra Nasnwa ${ }^{1}$, S.L. Godara ${ }^{1}$ and Manjeet Singh ${ }^{2 *}$ \\ ${ }^{1}$ Department of Plant Pathology, COA Bikaner, India \\ ${ }^{2}$ Department of Plant Pathology, CCS Haryana Agricultural University, Hisar, \\ Haryana, India \\ *Corresponding author
}

\section{A B S T R A C T}

Keywords

Pearl millet, Leaf spot, Management, Fungicides Drechslera setariae

Article Info

Accepted:

20 March 2018

Available Online:

10 April 2018
Foliar application of fungicides was found to be highly effective against leaf spot disease of pearl millet and resulted in increased grain yield, length of spike, plant height and reducing per cent disease intensity. Two sprays of propiconazole 25 EC @ $0.2 \%$ at fifteen days interval found to be highly effective against leaf spot of pearl millet followed by tebuconazole $25 \mathrm{EC}$ @ $0.2 \%$ and carbendazim $12 \mathrm{WP}+$ mancozeb $63 \mathrm{WP} @ 0.2 \%$. Propiconazole 25 EC @ 0.2\% has highest avoidable loss in grain yield. This treatment also increased the grain yield, length of spike, plant height with highest disease control efficacy.

\section{Introduction}

Pearl millet [Pennisetum glaucum (L.) R. Br.] $2 \mathrm{n}=14$ commonly known as bajra, sajja, combo, bari, ganti or kambam, is an allogamous crop having protogynous nature. It belongs to family Poaceae. It is an important food and forage crop in Asia, Africa and important forage in America. It has great potential because of its suitability to the extreme limits of agriculture. The pearl millet grains are very good nutritious and form the staple food or diet of approximately ten per cent of population in India. It has high quality protein with superior amino acid profile. It is a good source of protein $(11.5 \%)$, fat (4.1$6.4 \%)$, carbohydrate (59.8-78.2\%) and also rich in good amount of minerals particularly phosphorus and iron (2.8\%). India is the largest producer of pearl millet with annual production of 9.25 million tonnes from an area of 7.0 million hectares with productivity 1250 $\mathrm{kg} / \mathrm{ha}$ (Anonymous, 2014-15a). Pearl millet is mainly grown in Rajasthan, Haryana, Uttar Pradesh, Madhya Pradesh, Gujarat, Maharashtra, Karnataka, Tamil Nadu, and Andhra Pradesh states of the country. Rajasthan occupies first position in area and production of pearl millet in India. In Rajasthan, it is cultivated on 40.76 lac hectare 
area with the production 44.56 lac tonne and productivity $1093 \mathrm{~kg} / \mathrm{ha}$ (Anonymous, 201415b). Major pearl millet producing districts of Rajasthan are Bharatpur, Alwar, Karoli, Dholpur, Swai Madhopur, Barmer, Jhunjhunu, Jaisalmer, Churu, Jaipur, and Bikaner. Leaf spot of pearl millet comes every year in almost all the pearl millet growing area including Rajasthan. Among the various diseases of pearl millet, leaf spot incited by the fungus Drechslera setariae has attained the status of the economically important disease. The disease is characterized by the presence lesions have dark margins and ash coloured centers vary in size and sometimes blight the leaves completely.

Leaf spot of pearl millet is a common foliar disease caused by Drechslera setariae. Drechslera setariae was isolated from the rotted seeds and infected parts of seedlings. The seed used was obtained from Mysore (Karnataka), India and was found to be infected with Drechslera setariae, which has been reported from the United States to be seed borne in pearl millet, causing seed rot, blight and leaf spotting (Wells and Winstead, 1965; Wells and Burton, 1967). The disease has also been noticed in India by Bhowmik (1972) and Balasubramanian (1980).

\section{Materials and Methods}

The efficacy of selected fungicides evaluated against Drechslera setariae at two concentrations ( 0.1 and 0.2 per cent) under field conditions during kharif 2015.

Experiments on management of leaf spot disease by fungicides were conducted on research farm of College of Agriculture, Bikaner (Rajasthan). Seven fungicides viz., mancozeb 75 WP, chlorothalonil 75 WP, hexaconazole $5 \mathrm{EC}$, propiconazole $25 \mathrm{EC}$, difenconazole $25 \mathrm{EC}$, carbendazim $12 \mathrm{WP}+$ mancozeb $63 \mathrm{WP}$, tebuconazole $25 \mathrm{EC}$ at 0.1 and 0.2 per cent concentration were evaluated as foliar spray (Table 1). Pearl millet variety RHB-177 was shown in $5 \times 3.6 \mathrm{~m}^{2}$ plot size with $45 \times 15 \mathrm{~cm}$ row to row and plant to plant spacing on July, 2015. The trial was laid out in random block design with three replications.

Two sprays of each fungicide were made starting from first appearance of the disease and second spray at fifteen days interval. Before first spray, the crop was inoculated by suspension twice to ensure the proper disease development. Observations on disease intensity were recorded at 7 days interval from randomly selected plants in each replication of a treatment using 0-9 scale (Neal et al., 1971). Yield (q/ha), length of spike $(\mathrm{cm})$ and plant height $(\mathrm{cm})$ was also recorded.

Sum of all numerical ratings Per cent Disease intensity $=$ $x 100$

Total number of plant observed $\mathrm{x}$ Maximum grade

\section{Results and Discussion}

The efficacy of fungicides viz., mancozeb 75 WP, chlorothalonil $75 \mathrm{WP}$, hexaconazole 5 EC, propiconazole 25 EC, difenconazole 25EC, carbendazim $12 \mathrm{WP}+$ mancozeb 63 WP, tebuconazole $25 \mathrm{EC}$ ( 0.1 and 0.2 per cent of each) evaluated against leaf spot disease of pearl millet under field conditions. All the fungicides were found to be significantly superior over check in controlling the disease during kharif 2015 (Table 2). The minimum disease intensity was recorded with Propiconazole $(9.62 \%)$ followed by tebuconazole (14.07\%), carbendazim + mancozeb (16.29\%), difenconazole (23.71\%), hexaconazole $(42.96 \%)$, mancozeb $(47.40 \%)$ and chlorothalonil $(50.38 \%)$ at 0.2 per cent concentration (Table 2). Per cent disease intensity ranged from 21.48 to 52.57 and 9.62 to 47.40 per cent at 0.1 and 0.2 per cent concentration. 
Table.1 Selected fungicides used for control of leaf spot disease of pearl millet

\begin{tabular}{|l|l|l|l|l|}
\hline S. No. & Trade name & Common name & \multicolumn{2}{|c|}{ Doses (\%) } \\
\hline $\mathbf{1}$ & Dithane M-45 & Mancozeb 75 WP & 0.1 & 0.2 \\
\hline $\mathbf{2}$ & Kavach & Chlorothalonil 75 WP & 0.1 & 0.2 \\
\hline $\mathbf{3}$ & Contaf & Hexaconazole 5 EC & 0.1 & 0.2 \\
\hline $\mathbf{4}$ & Tilt & Propiconazole 25 EC & 0.1 & 0.2 \\
\hline $\mathbf{5}$ & Score & Difenconazole 25EC & 0.1 & 0.2 \\
\hline $\mathbf{6}$ & Companion & Carbendazim 12 WP + Mancozeb 63 WP & 0.1 & 0.2 \\
\hline $\mathbf{7}$ & Folicur & Tebuconazole 25 EC & 0.1 & 0.2 \\
\hline $\mathbf{8}$ & Control* & - & - & - \\
\hline *Without fungicide & & &
\end{tabular}

Table.2 The efficacy of fungicides against leaf spot disease of pearl millet under field conditions (kharif, 2015)

\begin{tabular}{|c|c|c|c|c|c|c|c|c|c|}
\hline Fungicides & $\begin{array}{c}\text { Conc. } \\
(\%)\end{array}$ & $\begin{array}{c}\text { Disease } \\
\text { intensity }(\%)\end{array}$ & $\begin{array}{c}\text { Disease } \\
\text { control } \\
(\%)\end{array}$ & $\begin{array}{c}\text { Grain } \\
\text { yield } \\
\text { (q/ha) }\end{array}$ & $\begin{array}{c}\text { Yield } \\
\text { increased } \\
\text { over the } \\
\text { control } \\
(\%)\end{array}$ & $\begin{array}{l}\text { Length } \\
\text { of } \\
\text { spike } \\
\text { (cm) }\end{array}$ & $\begin{array}{c}\text { Spike } \\
\text { length } \\
\text { increase } \\
\text { over } \\
\text { control } \\
(\%)\end{array}$ & $\begin{array}{c}\text { Plant } \\
\text { height } \\
\text { (cm) }\end{array}$ & $\begin{array}{l}\text { Plant } \\
\text { height } \\
\text { over } \\
\text { the } \\
\text { control } \\
(\%)\end{array}$ \\
\hline \multirow[t]{2}{*}{ Mancozeb } & 0.1 & $\begin{array}{c}51.33 \\
(45.76)^{*}\end{array}$ & 41.28 & 14.90 & 23.86 & 16.00 & 22.14 & 167.20 & 7.56 \\
\hline & 0.2 & $47.40(43.50)$ & 45.77 & 17.60 & 46.30 & 19.90 & 51.91 & 172.07 & 10.69 \\
\hline \multirow[t]{2}{*}{ Chlorothalonil } & 0.1 & $52.57(46.47)$ & 39.86 & 14.00 & 20.53 & 15.50 & 18.32 & 166.10 & 6.85 \\
\hline & 0.2 & $50.38(45.21)$ & 42.37 & 14.50 & 41.32 & 19.50 & 48.86 & 170.08 & 9.41 \\
\hline \multirow[t]{2}{*}{ Hexaconazole } & 0.1 & $44.44(41.81)$ & 49.16 & 15.20 & 26.35 & 16.15 & 23.29 & 167.90 & 8.00 \\
\hline & 0.2 & $42.96(40.95)$ & 50.85 & 18.00 & 49.62 & 20.07 & 53.21 & 172.85 & 11.19 \\
\hline \multirow[t]{2}{*}{ Propiconazole } & 0.1 & $21.48(27.61)$ & 75.42 & 19.40 & 61.27 & 18.99 & 44.97 & 175.93 & 13.17 \\
\hline & 0.2 & $9.62(18.06)$ & 88.99 & 22.10 & 83.70 & 23.33 & 77.32 & 179.10 & 15.21 \\
\hline \multirow[t]{2}{*}{ Difenconazole } & 0.1 & $42.95(40.95)$ & 50.86 & 16.70 & 38.42 & 16.40 & 25.19 & 168.16 & 8.18 \\
\hline & 0.2 & $23.71(29.14)$ & 72.87 & 19.30 & 60.43 & 20.40 & 55.73 & 173.08 & 11.34 \\
\hline \multirow[t]{2}{*}{$\begin{array}{l}\text { Carbendazim } \\
+ \text { mancozeb }\end{array}$} & 0.1 & 34.07 (35.71) & 61.02 & 17.50 & 45.47 & 16.11 & 22.98 & 171.21 & 10.14 \\
\hline & 0.2 & $16.29(23.80)$ & 81.36 & 19.77 & 64.34 & 21.10 & 61.07 & 175.49 & 12.89 \\
\hline \multirow[t]{2}{*}{ Tebuconazole } & 0.1 & $28.15(32.04)$ & 67.80 & 18.10 & 50.46 & 17.11 & 30.60 & 174.15 & 12.03 \\
\hline & 0.2 & $14.07(22.03)$ & 83.90 & 21.42 & 78.06 & 22.10 & 68.70 & 178.07 & 14.55 \\
\hline Control & - & $87.42(69.22)$ & - & 12.03 & - & 13.10 & - & 155.45 & - \\
\hline $\mathrm{SEm} \pm$ & & 0.42 & & 0.43 & & 0.45 & & 1.51 & \\
\hline $\mathrm{CD}$ at $5 \%$ & & 1.21 & & 1.25 & & 1.28 & & 4.35 & \\
\hline
\end{tabular}

\footnotetext{
* Figures given in parenthesis are angular transformed values
} 

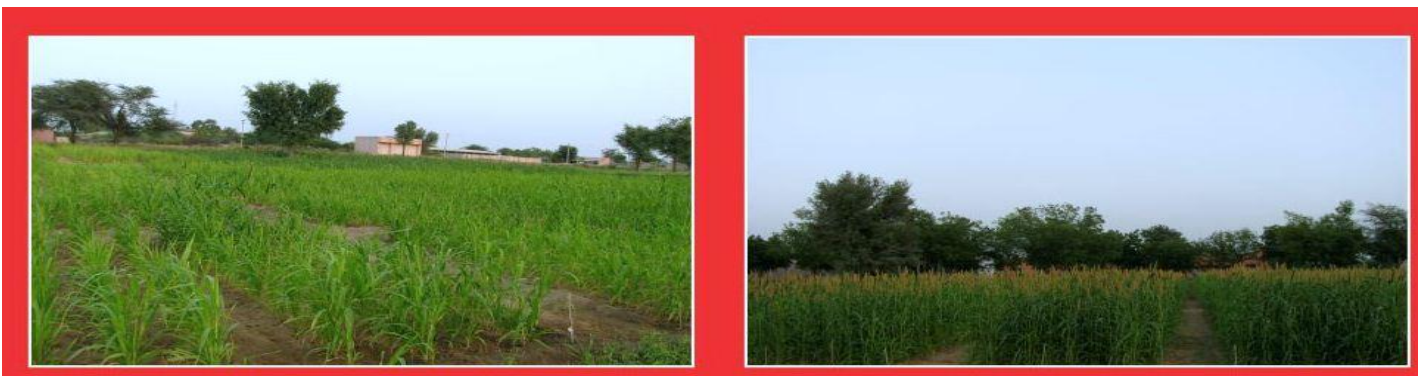

Plate : 1 A view of field experiment of pearl millet

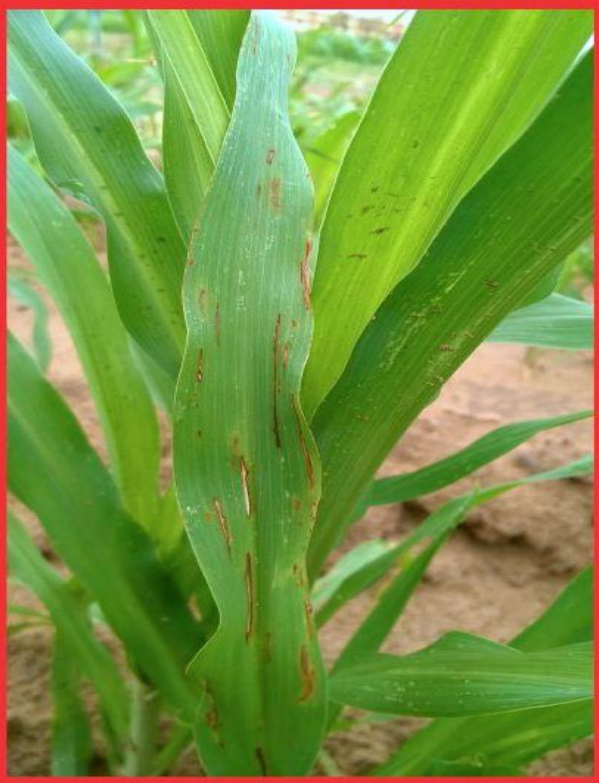

Leaf spot infected plants

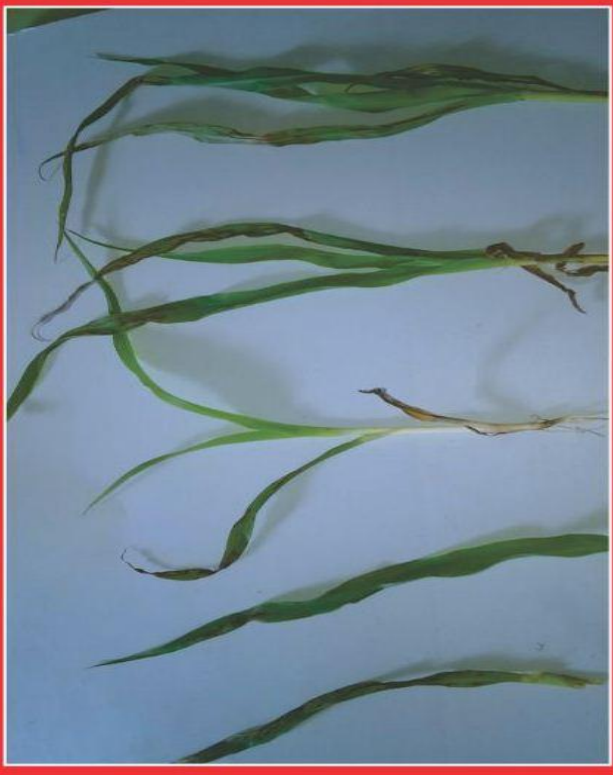

Infected seedling

Plate.2 Rating scale of leaf spot of pearl millet

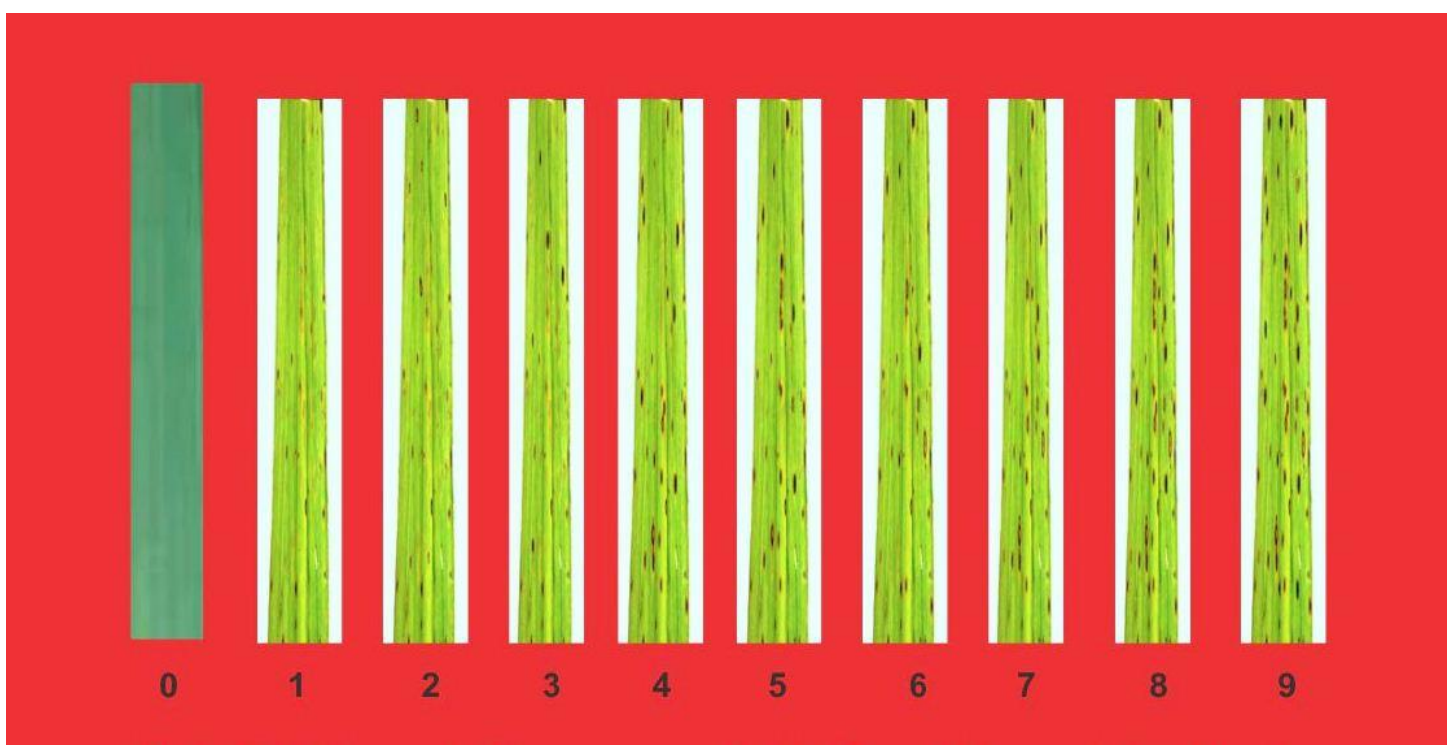




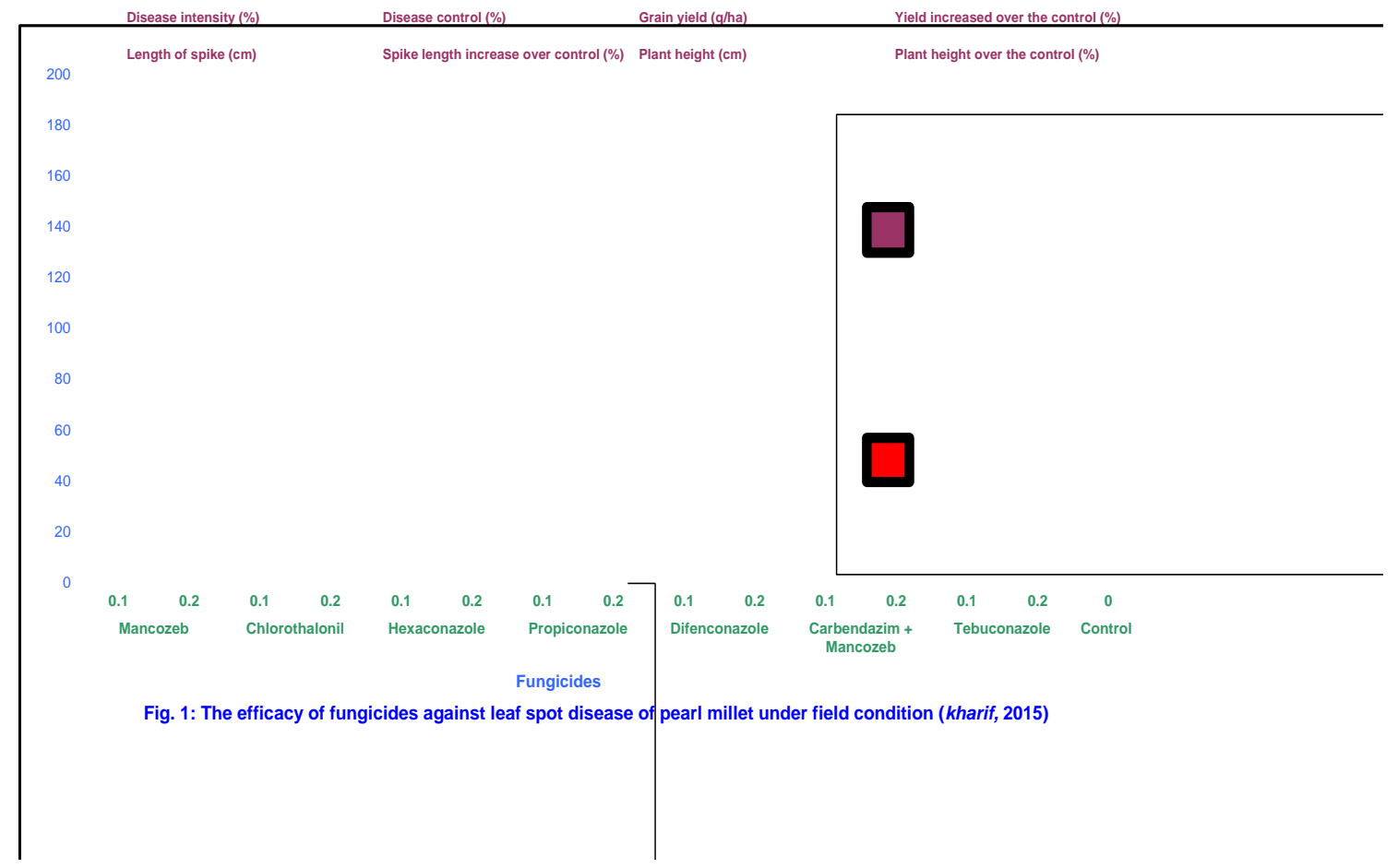

It is concluded that when increase the concentration of fungicide then decrease the per cent disease intensity in all the selected fungicides. However, propiconazole was highly effective, significantly superior and recorded maximum disease control $(88.99 \%)$ followed by tebuconazole $(83.90 \%)$ and carbendazim + mancozeb $(81.36 \%)$, difenconazole $(72.87 \%)$, hexaconazole $(50.85 \%)$ and mancozeb $(45.77 \%)$. Chlorothalonil was least effective fungicide which gave minimum disease control $(32.45 \%)$ at 0.2 per cent concentration against leaf spot disease of pearl millet during kharif 2015.

Similarly, fungicidal foliar sprays against leaf spot disease of pearl millet were significant effective on grain yield, length of spike and plant height. Analysis of grain yield, length of spike and plant height data revealed that two sprays with propiconazole $(0.2 \%)$ gave maximum yield of $22.10 \mathrm{q} / \mathrm{ha}$, maximum spike length $23.33 \mathrm{~cm}$ and maximum plant height $179.10 \mathrm{~cm}$ followed by tebuconazole $(0.2 \%)$, at the $21.42 \mathrm{q} / \mathrm{ha}, 22.10 \mathrm{~cm}$ and
$178.07 \mathrm{~cm}$ and carbendazim + mancozeb $(0.2 \%), 19.77 \mathrm{q} / \mathrm{ha}, 21.10 \mathrm{~cm}$ and $175.49 \mathrm{~cm}$, difenconazole $(0.2 \%), 19.30 \mathrm{q} / \mathrm{ha}, 20.40 \mathrm{~cm}$ $173.08 \mathrm{~cm}$, hexaconazole $(0.2 \%), 18.00 \mathrm{q} / \mathrm{ha}$, $20.07 \mathrm{~cm}, 172.85 \mathrm{~cm}$ and mancozeb $(0.2 \%)$, $17.60 \mathrm{q} / \mathrm{ha}, 19.90 \mathrm{~cm}, 172.07 \mathrm{~cm}$, respectably over check which gave grain yield (12.03 $\mathrm{q} / \mathrm{ha})$, spike length $(13.10 \mathrm{~cm})$ and plant height $(145.55 \mathrm{~cm})$ (Table 2). The lowest grain yield $14.00 \mathrm{q} / \mathrm{ha}$, length of spike 15.50 $\mathrm{cm}$ and plant height $160.10 \mathrm{~cm}$ were recorded in Chlorothalonil at both $(0.1$ and $0.2 \%)$ the concentrations.

In the present investigation, fungicides studies were also done to find out the efficacy on disease control against leaf spot, grain yield and length of spike and plant height in pearl millet cultivar RHB-177. Total seven fungicides tested viz., mancozeb $75 \%$ WP (Dithane M-45), chlorothalonil 75\% WP (Kavach), hexaconazole 5\% EC (Contaf), propiconazole $25 \%$ EC (Tilt), difenaconazole $25 \%$ EC (Score), carbendazim 12\% WP + Mancozeb 63\% WP (Companion) and tebuconazole $25 \% \mathrm{EC}$ (folicur) at 0.1 and 0.2 
per cent concentrations were evaluated against leaf spot disease of pearl millet under field conditions during kharif 2015. Among these fungicides tested for the management of leaf spot disease of pearl millet, Propiconazole $(0.2 \%)$ and tebuconazole $(0.2 \%)$, they performed better as compared to other fungicides and also found significantly higher grain yield, spike length and plant height. The minimum per cent disease control were recorded with both the concentrations of chlorothalonil $(0.1$ and $0.2 \%)$, followed by mancozeb $(0.1 \%$ and $0.2 \%)$ over check. The observations are also in confirmation with result obtained by Sunder et al., (2004) they reported that amongst 7 fungicides evaluated under in vitro, hexaconazole and propiconazole were most in inhibitory to mycelial growth of Drechslera oryzae followed by iprobenphos and edifenphos. Under field trials, both the fungicides reduced the leaf spot disease by 86.2 and 78.7 per cent accompanied with an increase of 14.6 and 14.2 per cent in grain yield followed by mancozeb and edifenphos. Hossain and Hossain (2011) the evaluated that efficacy of benzothiozole $(50 \mathrm{mg} / \mathrm{l})$, azoxystrobin $(1 \mathrm{ml} / \mathrm{l})$ and propiconazole $(1 \mathrm{ml} / \mathrm{l})$ for controlling brown spot and narrow brown spot disease of rice under in vivo conditions. The resulted in marked significantly reduced brown spot and narrow brown spot disease and higher grain yield over the control when sprayed at tillering stage. Kumar et al., (2013), they evaluated systemic and contact fungicides, among four systemic fungicides, carbendazim + mancozeb found most effective followed by difenconazole and among five contact fungicides, mancozeb found most effective followed by captan, least effective was chlorothalonil in inhibiting the mycelial growth of Drechslera setariae. Among the 8 fungicides tested against Cochliobolus miyabeanus (Drechslera sp.), Propiconazole $25 \%$ EC gives the highest radial growth inhibition $(89.16 \%)$ of the fungus followed by
Carbendazim 12\%+Mancozeb $63 \% \quad$ WP, Hexaconazole 4\%+Zineb $68 \%$ WP, Mancozeb 75\% WP and Difenoconazole 25\% EC showing $88.33 \%, 87.49 \%, 87.49 \%$ and $83.89 \%$ growth inhibitions, respectively (Hemayatullah et al., 2014; Jayasena, et al., 2002). Gupta et al., (2013) tested seven fungicides viz., propiconazole, tricyclazole, hexaconazole, tridimefon, carbendazim, mancozeb and azoxystrobin at different concentrations against Bipolaris oryzae causing brown spot disease of rice, propiconazole was found most effective with maximum growth inhibition (97\%) at 250 ppm concentration, tricyclazole and propiconazole at 0.1 per cent significantly reduced the disease severity under field conditions. Lore et al., (2007) evaluated the efficacy of Tilt (propiconazole) $25 \mathrm{EC}$ at $0.1 \%$ was the most effective fungicide against the three diseases, where the lowest mean disease severity was $9.0 \%$ for brown spot $15.7 \%$ for sheath blight and $6.7 \%$ for sheath rot as compared to $48.5 \%, 51.4 \%$ and $24.8 \%$ in controls.

Further, it can be concluded that minimum disease intensity 9.62 per cent of leaf spot and maximum grain yield $22.10 \mathrm{q} / \mathrm{ha}$, maximum spike length $23.33 \mathrm{~cm}$ and maximum plant height $179.10 \mathrm{~cm}$ were recorded in propiconazole (Tilt) followed by tebuconazole (Folicur), and carbendazim + mancozeb (companion) at $0.2 \%$ concentration. Chlorothalonil (Kavach) was found least effective fungicide and recorded maximum disease intensity, minimum per cent of leaf spot and minimum grain yield, minimum spike length and minimum plant height Among the selected fungicides minimum per cent disease intensity, maximum per cent disease control, maximum grain yield $(\mathrm{g} / \mathrm{ha})$, maximum per cent yield increased over the control, maximum length of spike $(\mathrm{cm})$, maximum per cent spike length increase over control, maximum plant height 
(cm) and maximum per cent plant height over control was recorded at 0.2 per cent concentration as compare to 0.1 per cent concentration.

\section{References}

Anonymous, 2014-2015a. Ministry of Agriculture, Govt. of India.

Anonymous, 2014-2015b. Department of Agriculture, Govt. of Rajasthan.

Balasubramanian, K. A. 1980. Association of Drechslera setariae with downy mildew affected pearl millet. Curr. Sci. 49 (6): 233-234.

Bhowmik, T. P. 1972. Bipolaris setariae on two new host in india. Indian Phytopathol. 25: 590-591.

Gupta, V., Shamas, N., Razdan, V. K., Sharma, B. C., Sharma, R., Kaur, K., Singh, I., John, D. and Kumar, A. 2013. Foliar application of fungicides for management of brown spot disease in rice (Oryza sativa L.) caused by Bipolaris oryzae. African J. Agril Res. 8 (25): 3303-3309.

Hemayatullah, and Mahapatra, S. S. 2014. Chemical management of brown spot disease of rice in Odisha. $\mathrm{J} . \mathrm{Pl}$. Protec. Environ. 11 (2): 67-70.

Hossain, I., Dey, P. and Hossain, M. Z. 2011. Efficacy of Bion, Amistar, Tilt in controlling brown spot and narrow brown spot of rice cv.BR11 (Mukta). $J$. Bangladesh. Agril. Univ. 9 (2): 201204.

Jayasena, K. W., Loughman, R. and Majewski, J. 2002. Evaluation of fungicides in control of spot-type net blotches on barley. Crop Protec. 21 (1): 63-69.

Kumar, K.A.C., Nagaraja, A., Raghavendra, B.T. and Ravikumara, B.M. 2013. Evaluation of fungicides against Drechslera setariae causing brown leaf spot of foxtail millet [Setaria italica (L.)]. Environ. Ecol. 31(2A): 801-803.

Lore, J. S., Thind, T. S., Hunjan, M. S. and Goel, R. K. 2007. Performance of different fungicides against multiple diseases of rice. Indian Phytopath. 60 (3): 296-301.

Neal, F.H.M., Konzak, C. F., Smith, E. P., Tats, W. S. and Russell, T. S. 1971. A uniform system for recording and processing cereal research data USDA. D. C., ARS, Washington. Agric. Res. Serv. 42: 34-121.

Sunder, S., Singh, R., Dodan, D. S. and Mehla, D. S. 2004. Effect of different nitrogen levels on brown spot (Drechslera oryzea) of rice and its management through host resistance and fungicides. Pl. Dis. Res. 20 (2): 111-114.

Wells, H. D. and Burton, G. W. 1967. Helminthosporium setariae on pearl millet, Pennisetum typhoides, as affected by age of host differences. Crop Sci. 7: 621-622.

Wells, H. D. and Winstead, E. E. 1965. Seed borne fungi in Georgia grown and western grown pearl millet seed on safe in Georgia during 1960. Pl. Dis. Rep. 49: 487-489.

\section{How to cite this article:}

Rajendra Nasnwa, S.L. Godara and Manjeet Singh. 2018. Evaluation of Fungicides against Leaf Spot Disease of Pearl Millet Caused by Drechslera setariae under Field Conditions. Int.J.Curr.Microbiol.App.Sci. 7(04): 2282-2288. doi: https://doi.org/10.20546/ijcmas.2018.704.261 